\title{
Modul tutorial sebagai media pembelajaran pencak silat untuk siswa sekolah menengah kejuruan
}

\author{
Guntur Eko Saputro ${ }^{1}$, Yulingga Nanda Hanief ${ }^{1}{ }^{*}$, Reo Prasetiyo Herpandika ${ }^{1}$, \\ Deny Pradana Saputro ${ }^{2}$ \\ ${ }^{1}$ Program Studi Pendidikan Jasmani Kesehatan dan Rekreasi, Fakultas Keguruan dan Ilmu \\ Pendidikan, Universitas Nusantara PGRI Kediri. Jalan KH Achmad Dahlan, No 76 Mojoroto, Kota \\ Kediri 64112, Indonesia \\ ${ }^{2}$ Sekolah Tinggi Keguruan dan Ilmu Pendidikan (STKIP) Rokania. Jl. Raya Pasir Pengaraian, Km 15 \\ Langkitin, Rambah Samo, Kab. Rokan Hulu, Riau, Indonesia \\ * Corresponding Author. E-mail: yulingganandahanief@gmail.com \\ Received: 1 September 2018; Revised: 19 September 2018; Accepted: 1 October 2018
}

\begin{abstract}
Abstrak
Penelitian bertujuan untuk menghasilkan modul tutorial pembelajaran pencak silat yang dapat digunakan guru SMK dalam mata pelajaran Penjasorkes. Penelitian ini melalui 9 tahapan dengan mengadaptasi penelitian dan pengembangan pendidikan model Sugiyono. Subjek penelitian adalah siswa SMK 1 Ngunut Kabupaten Tulungagung. Instrumen berupa kuesioner. Hasil penelitian berupa modul tutorial pembelajaran pencak silat yang terdiri dari: (1) teknik dasar pukulan; (2) teknik dasar tendangan; dan (3) sikap pencak silat. Model disusun dalam bentuk buku panduan dengan judul "Modul Pembelajaran Pencak Silat untuk kelas XI SMA dan SMK". Berdasarkan penilaian para ahli materi, ahli media dan guru, dapat disimpulkan bahwa pengembangan modul tutorial pembelajaran pencak silat untuk siswa SMK layak digunakan dalam pembelajaran pencak silat untuk siswa SMK.
\end{abstract}

Kata Kunci: modul, tutorial, pencak silat, siswa SMK.

\section{Tutorial module as pencak silat learning media for vocational high school students}

\begin{abstract}
The study aims at generating a tutorial module as pencak silat learning media that might be used by the vocational high school teachers in Sport, Health and Physics Education. The study was conducted through 9 stages that had been adopted from the research and development model by Sugiyono. The subjects in the study were the students of Negeri 1 Ngunut State Vocational High School in the Regency of Tulungagung. Then, the necessary data for the study were gathered through instrument. The results of the study generate a tutorial module for Pencak Silat Learning media that consists of: (1) fundamental techniques of punch; (2) fundamental technique of kick; and (3) body posture of pencak silat. The model was designed in the form of guidebook entitled "Modul Pembelajaran Pencak Silat untuk Kelas XI SMA dan SMK" ("Pencak Silat Learning Module for Grade XI Senior and Vocational High Schools"). Based on the judgment by the material experts, the media experts and the teachers it might be concluded that the tutorial module as the pencak silat learning media that has been developed is already feasible for implementation among the vocational high school students.
\end{abstract}

Keywords: module, tutorial, pencak silat, vocational student.

How to Cite: Saputro, G., Hanief, Y., Herpandika, R., \& Saputro, D. (2018). Modul tutorial sebagai media pembelajaran pencak silat untuk siswa sekolah menengah kejuruan. Jurnal Keolahragaan, 6(2), 130-138. doi:https://doi.org/10.21831/jk.v0i0.21099

https://doi.org/10.21831/jk.v0i0.21099 


\section{PENDAHULUAN}

Pencak silat adalah hasil budaya manusia Indonesia untuk membela/mempertahankan eksistensi (kemandirian) dan intengritasnya (manunggalnya) terhadap lingkungan hidup/ alam sekitarnya untuk mencapai keselarasan hidup guna meningkatkan iman dan taqwa kepada Tuhan Yang maha Esa (Nurkholis \& Weda, 2015). Menanamkan nilai-nilai yang ada dalam pencak silat juga merupakan bagian dari pelestarian nilai-nilai budaya bangsa yang selama ini dijunjung tinggi oleh masyarakat sejak jaman dulu sampai sekarang. Selain kaya akan teknikteknik perlindungan diri, pencak silat juga sarat akan nilai-nilai luhur. Nilai-nilai luhur pencak silat terdiri dari 4 aspek, yaitu aspek mental spiritual, aspek olahraga, aspek seni, dan aspek beladiri (Gristyutawati, Purwono, \& Widodo, 2012).

Pencak silat sangat baik untuk diajarkan dan dikembangkan pada siswa menengah atas. Melalui pendidikan jasmani, pencak silat dikenalkan dengan konsep pembelajaran untuk membentuk manusia yang berbudi luhur. Guru menyusun materi menjadi beberapa bagian sesuai teknik dasar pencak silat dengan tujuan untuk mengembangkan keterampilan motorik pada siswa. Apabila dikaji berdasarkan teknik dasar, pencak silat menuntut seseorang untuk selalu kuat, energik, kokoh dan sigap. Oleh karena itu, pencak silat sangat sesuai dengan tujuan pendidikan jasmani yaitu meningkatkan pertumbuhan baik secara fisik maupun psikis.

Pendidikan jasmani merupakan bagian yang tidak dapat dipisahkan dari kehidupan manusia, melalui pendidikan jasmani manusia dapat belajar lebih banyak hal yang berhubungan dengan afektif, kongnitif, dan psikomotor yang merupakan bekal manusia untuk mencapai tujuan hidup (Hanief \& Sugito, 2015). Pendidikan jasmani, olahraga, dan kesehatan (penjasorkes) pada dasarnya merupakan bagian integral dari sistem pendidikan secara keseluruhan, bertujuan untuk mengembangkan aspek kesehatan, kebugaran jasmani, keterampilan berpikir kritis, stabilitas emosional, keterampilan sosial, penalaran, dan tindakan moral melalui aktivitas jasmani dan olahraga (Artyhadewa, 2017).

SMK Ngunut Kabupaten Tulungagung merupakan salah satu sekolah menengah kejuruan yang dalam pembelajaran dan sarana prasarana olahraga cukup memadai terutama pada bidang pencak silat. Berdasarkan hasil observasi dan wawancara peneliti kepada siswa. Perleng- kapan dan sarana di SMK Ngunut Kabupaten Tulungagung tidak dimanfaatkan secara maksimal. Misalnya, pada mata pelajaran pencak silat masih menggunakan metode ceramah dan praktek guru (demonstrasi) dalam kegiatan pembelajaran. Belum ada media pembelajaran yang digunakan guru untuk melakukan pembelajaran dalam mata pelajaran pencak silat. Hal seperti ini kadang-kadang membuat siswa ada yang kurang tanggap dalam penerimaan materi secara lisan, kadang membuat siswa yang duduk dibarisan belakang kurang jelas atau malah ada yang tidak memperhatikan sama sekali, maka hasil belajar yang diperoleh siswa pun kurang maksimal dikarenakan beberapa faktor siswa cepat bosan dengan materi yang diberikan, tidak ada hal baru yang membuat siswa merasa tertantang untuk mempelajari materi lebih dalam lagi, suara guru yang terkadang kurang menjangkau siswa yang ada dibarisan belakang dan banyaknya siswa saat praktek mengobrol dengan temannya sendiri sehingga tidak jarang mereka ketinggalan penjelasan yang diberikan gurunya. Hal ini diperkuat dengan minimnya jumlah buku ajar, buku materi, modul, maupun video pembelajaran pencak silat yang ada di sekolah tersebut. Sehingga siswa merasa kesulitan dalam mempelajari materi pencak silat yang berakibat pada minimnya penguasaan keterampilan gerak pada siswa. Fakta tersebut diperkuat oleh hasil penelitian Kriswanto (2011) the levels of understanding of physical education teachers of junior high school in Sleman regency towards the pencak silat instructions, there were 3 teachers $(8 \%)$ in very high category, 13 teachers (34\%) in high category, 20 teachers (53\%) in the category low, and 2 teachers (5\%) in the poor category.

Permasalahan yang ada tersebut mengakibatkan siswa tidak dapat memahami dan menguasai teknik dasar pencak silat dengan baik. Perlu adanya jalan keluar agar kebutuhan akan gerak yang nantinya menunjang proses pertumbuhan dan perkembangan anak dapat terpenuhi dengan baik. Salah satu alternatif sebagai jalan keluarnya adalah perlu adanya media.

Media merupakan salah satu faktor yang mendukung keberhasilan proses pembelajaran di sekolah karena dapat membantu proses penyampaian informasi dari guru kepada siswa ataupun sebaliknya. Penggunaan media secara kreatif dapat memperlancar dan meningkatkan efesiensi pembelajaran sehingga tujuan pembelajaran dapat tercapai (Arda, Saehana, \& Darsikin, 2015). Akan tetapi, tidak semua materi pembelajaran, siswa dilibatkan pada objek yang sebenarnya, 
sehingga peranan media dalam pembelajaran sangat dibutuhkan.

Media pembelajaran sebagai salah satu sarana meningkatkan mutu pendidikan sangat penting dalam proses pembelajaran. Penggunaan media pendidikan dapat membantu proses belajar siswa dalam poses belajar mengajar yang pada gilirannya dapat mempertinggi hasil belajar yang dicapainya. Media pembelajaran menurut (Musfiqon, 2012) yaitu merupakan alat bantu fisik maupun nonfisik yang sengaja digunakan sebagai perantara antara guru dan siswa dalam memahami materi pembelajaran agar lebih efektif dan efisien. Jadi dapat disimpulkan bahwa media pembelajaran adalah seperangkat pembelajaran yang dirancang sebagai prantara antara guru dan siswa dalam penyampaian materi pembelajaran yang lebih efektif dan efisien.

Media dalam pembelajaran berfungsi memperjelas pesan yang disampaikan guru (Primasari, Zulfiani, \& Herlanti, 2014). Menurut Suryosubroto (2009) mengatakan bahwa penyediaan media pengajaran yang bermacam-macam akan sangat berguna bagi anak untuk belajar sesuai dengan cara belajar yang berbeda-beda. Pemakaian media pembelajaran dalam proses belajar mengajar dapat membangkitkan keinginan dan minat yang baru, membangkitkan motivasi dan rangsangan kegiatan belajar dan bahkan membawa pengaruh-pengaruh psikologis terhadap siswa (Nugrahani, 2007).

Dalam praktek sehari-hari telah banyak guru, dosen dan tenaga pengajar lainnya yang telah menerapkan media pembelajaran. Media pembelajaran yang diterapkan sangat bervariasi, tergantung situasi, kondisi dan kebutuhan.Salah satunya hasil riset yang dilakukan oleh (Arda et al., 2015) yaitu pengembangan media pembelajaran interaktif berbasis computer untuk siswa SMP kelas VIII yang mana hasil dari penelitian tersebut menunjukkan bahwa media pembelajaran interaktid berbasis computer yang dikembangkan dengan menggunakan macromedia flash 8 layak digunakan sebagai media pembelajaran untuk meningkatkan pemahaman konsep.

Banyak media yang dapat dipilih oleh guru dalam menyampaikan materi kepada siswa. Terlebih lagi pada zaman now yang semakin maju, teknologi semakin canggih dan dapat memudahkan kegiatan manusia, termasuk dapat memudahkan proses pembelajaran. Seiring dengan perkembangan teknologi yang semakin maju, media pembelajaran dapat dikembangakan terus menerus sehingga lebih baik lagi dari sebelumnya. Media pembelajaran ada yang berbasis visual, salah satu media pembelajaran yang termasuk dalam media pembelajaran berbasis visual adalah modul.

Modul merupakan bahan ajar cetak yang dirancang untuk dapat dipelajari secara mandiri oleh peserta pembelajaran. Modul pembelajaran merupakan satuan program belajar mengajar yang terkecil, yang dipelajari oleh siswa sendiri secara perseorangan atau diajarkan oleh siswa kepada dirinya sendiri self-instructional (Susilo, Siswandari, \& Bandi, 2016). Modul disebut juga media untuk belajar mandiri karena di dalamnya telah dilengkapi petunjuk untuk belajar sendiri. Artinya, pembaca dapat melakukan kegiatan belajar tanpa kehadiran pengajar secara langsung. Bahasa, pola, dan sifat kelengkapan lainnya yang terdapat dalam modul ini diatur sehingga ia seolah-olah merupakan "bahasa pengajar" atau bahasa guru yang sedang memberikan pengajaran kepada murid-muridnya. Oleh karena itu, media ini sering disebut bahan instruksional mandiri. Pengajar tidak secara langsung memberi pelajaran atau mengajarkan sesuatu kepada para muridmuridnya dengan tatap muka, tetapi cukup dengan modul-modul ini (Prastowo, 2012). Hasil riset yang dilakukan oleh Lestari (2014) dengan judul "Pembuatan Bahan Ajar Berbasis Modul pada Matakuliah Media Pembelajaran di Jurusan Tarbiyah STAIN Sultan Qaimuddin Kendari" menyatakan bahwa penggunaan modul didasarkan pada fakta bahwa jika peserta didik diberikan waktu dan kondisi belajar memadai maka akan menguasai suatu kompetensi secara tuntas. Dengan adanya modul yang sesuai dengan karakteristik siswa dan tujuan pembelajaran maka tingkat pemahaman siswa terhadap pelajaran akan meningkat.

Secara garis besar, penyusunan modul atau pengembangan modul menurut Nasution dalam Lestari (2014) dapat mengikuti langkah- langkah berikut: (1) Merumuskan sejumlah tujuan secara jelas, spesifik, dalam bentuk kelakuan siswa yang dapat diamati dan diukur; (2) Urutan tujuan itu yang menentukan langkah-langkah yang diikuti dalam modul itu; (3) Tes diagnostik untuk mengukur latar belakang siswa, pengetahuan, dan kemampuan yang telah dimilikinya sebagai prasyarat untuk menempuh modul itu (Entry Behaviour atau Entering Behaviour); (4) Menyusun alasan atau rasional pentingnya modul ini bagi siswa. Ia harus tahu apa gunanya ia mempelajari modul ini, siswa harus yakin akan manfaat modul itu agar ia bersedia mempelajarinya dengan sepenuh tenaga; (5) Kegiatan-kegiatan belajar direncanakan untuk membantu dan membimbing 
siswa agar mencapai kompetensi-kompetensi seperti dirumuskan dalam tujuan. Kegiatan itu dapat berupa mendengarkan rekam-an, melihat film, mengadakan percobaan dalam laboratorium, mengadakan bacaan membuat soal, dan sebagainya. Perlu disediakan beberapa alternatif, beberapa cara yang dijalani oleh siswa sesuai dengan pribadinya. Bagian inilah yang merupakan inti modul, aspek yang paling penting dalam modul itu, karena menyangkut proses belajar itu sendiri; (6) Menyusun posttest untuk mengukur hasil belajar murid, hingga manakah dia menguasai tujuan-tujuan modul. Dapat pula disusun beberapa bentuk tes yang pararel. Butir-butir tes harus bertalian erat dengan tujuan-tujuan modul; (7) Menyiapkan pusat sumber-sumber berupa bacaan yang terbuka bagi siswa setiap waktu ia memerlukannya.

Secara teoritis penyusunan modul dimulai dengan perumusan tujuan, akan tetapi dalam prakteknya sering dimulai dengan penentuan topik dan bahan pelajarannya dapat dipecahkan dalam bagian-bagian yang lebih kecil yang akan dikembangkan menjadi modul. Baru sebagai langkah kedua, dirumuskan tujuan-tujuan modul yang berkenaan dengan bahan yang perlu dikuasai untuk mempersiapkan rancangan penulisan modul.

Penelitian ini bertujuan untuk mengembangkan modul tutorial sebagai media pembelajaran pencak silat untuk siswa. Harapannya, dengan adanya modul ini, guru tidak harus selalu mendemonstrasikan gerakan di depan siswa. Setelah guru memberikan contoh, selanjutnya siswa dapat mempelajari secara mandiri melalui modul tersebut. Yang lebih penting, siswa dapat mempelajari diluar jam mata pelajaran, sehingga memiliki banyak kesempatan untuk mempelajari berbagai gerak teknik dasar dalam pencak silat.

\section{METODE}

Penelitian ini merupakan penelitian pengembangan (Research \& Development). Langkah-langkah penelitian dan pengembangan menurut Sugiyono (2011) terdapat sepuluh langkah, yaitu:

\section{Potensi dan Masalah}

Pada tahap potensi dan masalah, peneliti melakukan observasi di sekolah SMK Ngunut Kabupaten Tulungagung dan mendapatkan data bahwa sekolah memiliki beberapa potensi antara lain memiliki matras yang digunakan untuk pertandingan pencak silat. Berdasarkan observasi yang telah dilakukan terdapat permasalahan yang menghambat pencapaian tujuan pembelajaran. Selama ini siswa kurang antusias dan kurang berminat apabila mendapatkan materi pencak silat.

\section{Mengumpulkan Informasi}

Langkah yang ditempuh penulis untuk mengumpulkan data adalah dengan observasi dan wawancara di SMK Ngunut Kabupaten Tulungagung. Observasi dilakukan dengan mengamati proses belajar mengajar. Wawancara dilakukan kepada pihak sekolah dalam hal ini bagian kurikulum dan guru mata pelajaran Pendidikan Jasmani Olahraga dan Kesehatan (PJOK).

Tujuan observasi dan wawancara adalah untuk mengetahui dan mendapatkan keterangan, gambaran serta masukan mengenai kondisi pembelajaran dan media apa yang selama ini digunakan dalam proses pembelajaran sehari-hari, sehingga dapat diketahui media yang tepat untuk dikembangkan dalam proses belajar. Dari pengumpulan data diperoleh materi PJOK Pencak Silat kelas XI seperti terlihat pada Tabel 1.

Tabel 1. Materi Pembelajaran Pencak Silat

\begin{tabular}{ll}
\hline \multicolumn{1}{c}{ Materi } & \multicolumn{1}{c}{ Kegiatan Pembelajaran } \\
\hline Aktivitas & Melakukan teknik dasar pencak \\
Beladiri & silat (pukulan, tendangan, \\
(Pencak silat) & tangkisan, hindaran, dan elakan) \\
& yang dilakukan (berpasangan \\
dan berkelompok) dengan & koordinasi yang baik. \\
& Melakukan variasi dan \\
& kombinasi teknik dasar pencak \\
& silat (pukulan, tendangan, \\
& tangkisan, hindaran dan elakan) \\
& yang dilakukan (berpasangan \\
& dan berkelompok) dengan \\
& koordinasi yang baik. \\
& Melakukan pertandingan pencak \\
& silat menggunakan peraturan \\
& yang dimodifikasi untuk \\
& menumbuhkan dan membina \\
& nilai-nilai kerjasama, kejujuran, \\
& menghargai, semangat, dan \\
& percaya diri. \\
\hline
\end{tabular}

Sumber: Silabus SMK Ngunut Kabupaten

Tulungagung, Tulungagung 2017

Sebagai referensi yang dibutuhkan isi dari materi yang dimasukkan pada media, maka penulis mengambil referensi dari buku-buku yang berkaitan dengan Pencak silat dan dari Internet. 


\section{Desain Produk}

Tahap ini, peneliti berusaha merancang modul tutorial pencak silat berdasarkan ketetapan Badan Standar Nasional Pendidikan (BSNP) diantaranya adalah aspek kelayakan isi, bahasa dan gambar, penyajian dan grafis.

\section{Validasi Desain}

Setelah desain selesai, peneliti menunjuk validator yang benar-benar kompeten. Validator yang ditunjuk meliputi validator materi dan ahli. Harapannya agar kualitas isi konten maupun grafis, benar-benar sesuai dengan apa yang hendak dicapai.

\section{Perbaikan Desain}

Pada tahap ini, peneliti berupaya memperbaiki apa yang menjadi saran maupun masukan dari para validator.

\section{Uji coba Produk}

Uji coba produ dikenakan pada siswa SMK Ngunut pada stau kelas.

\section{Revisi Produk}

Tahap ini merupakan tahap perbaikan pasca uji coba produk dalam skala kecil. Perbaikan yang dilakukan untuk mengarah pada uji skala besar.

\section{Uji coba Pemakaian}

Tahap ini produk yang dikembangkan di uji cobakan pada kelompok besar, yaitu siswa SMK Ngunut Kabupetn Tulungagung yang menjadi subyek pengembangan dan penelitian.

\section{Revisi Produk}

Tahap ini merupakan revisi akhir sebelum produk siap untuk di produk massal.

\section{Pembuatan Produk Masal}

Produk yang dikembangkan dilakukan produk secara massal dengan tujuan untuk mendistribusikan modul ke seluruh siswa.

Subjek uji coba dalam penelitian pengembangan ini adalah siswa SMK 1 Ngunut Kabupaten Tulungagung yang ditentukan peneliti. Tahap pertama adalah tahap uji coba produk dengan jumlah subjek 10 siswa, tahap kedua adalah uji coba pemakaian dengan subjek pene-litian 33 siswa. Teknik penentuan subjek uji coba dalam penelitian pengembangan ini dengan ditentukan dari (1) Tingkat kemampuan kognitif siswa yaitu, pintar, sedang, dan kurang; (2) Pe-nentuan jenis kelamin; (3) Tingkat kemampuan psikomotor siswa dari yang baik, sedang, kurang. Pemilihan siswa uji coba dilakukan oleh guru yang bersangkutan karena lebih memahami karakteristik siswa.

Instrumen yang digunakan untuk mengumpulkan data pada penelitian ini berupa kuesioner. Instrumen berupa kuesioner disusun dengan maksud untuk mengevaluasi kualitas modul pembelajaran pencak silat yang dipakai sebagai alat pengumpul data dari para ahli dan siswa sehubung dengan kritik, saran dan masukan yang bermanfaat bagi kualitas produk.

Data yang diperoleh melalui kegiatan uji coba diklasifikasikan menjadi dua yaitu data kualitatif dan kuantitatif. Data kualitatif diperoleh dari saran-saran, masukan, dan koreksi yang diberikan oleh ahli materi, ahli bahasa, dan ahli media terkait dengan kualitas modul pembelajaran pencak silat. Sedangkan teknik analisis data kuantitatif dalam penelitian ini menggunakan analisis statistik deskriptif, yang berupa pernyataan sangat kurang, kurang, cukup, baik, sangat baik yang diubah menjadi data kuantitatif dengan patokan 5 yaitu dengan penskoran dari angka $1 \mathrm{~s} / \mathrm{d}$ 5. Langkah-langkah dalam analisis data antara lain: (a). Mengumpulkan data kasar, (b). Pemberian skor, (c). Skor yang diperoleh kemudian dikonversikan dengan skala 5 dengan menggunakan acuan konversi dari Sukarjo yang dikutip oleh Suyatmin \& Widiyanto (2017) pada Tabel 2.

Tabel 2. Pedoman Konversi Data

\begin{tabular}{ccc}
\hline $\begin{array}{c}\text { Data } \\
\text { Kuantitatif }\end{array}$ & Rentang & $\begin{array}{c}\text { Data } \\
\text { Kualitatif }\end{array}$ \\
\hline 5 & $\mathrm{X}>\mathrm{Xi}+1,80 \mathrm{Sbi}$ & Sangat baik \\
4 & $\mathrm{Xi}+0,60<\mathrm{X} \leq \mathrm{Xi}+$ & Baik \\
& $1,80 \mathrm{Sbi}$ & \\
3 & $\mathrm{Xi}-0,60<\mathrm{X} \leq \mathrm{Xi}+$ & Cukup \\
& $0,60 \mathrm{Sbi}$ & \\
2 & $\mathrm{Xi}-1,680<\mathrm{X} \leq \mathrm{Xi}+$ & Kurang \\
& $0,60 \mathrm{Sbi}$ & Sangat \\
1 & $\mathrm{X} \leq \mathrm{Xi}+-1,80 \mathrm{Sbi}$ & kurang \\
\hline
\end{tabular}

Keterangan:

$\mathrm{Xi}$ : rerata ideal

$=1 / 2($ skor maksimal+skor minimal $)$

Sbi: simpangan baku ideal

$=1 / 6$ (skor maskimal - skor minimal $)$

$\mathrm{X}$ : skor aktual

Untuk memperoleh data rerata hasil penilaian yang akan digunakan sebagai kesimpulan menggunakan rumus:

Rerata Penilaian $=\left(\frac{\text { total penilaian }}{\sum \text { aspek yang di amati } x \sum \text { siswa }}\right)$ 


\section{HASIL DAN PEMBAHASAN}

\section{Hasil Pengembangan}

Penelitian ini bertujuan untuk menghasilkan modul tutorial pembelajaran pencak silat yang dapat digunakan guru SMK dalam mata pelajaran Penjasorkes. Penelitian ini merupakan penelitian pengembangan (Research \& Development).

Setelah menentukan materi yang akan dikembangkan, selanjutnya dilakukan proses desain untuk memproduksi modul pembelajaran dengan menggunakan langkah-langkah menyusun konsep produk, mengumpulkan bahanbahan, dan membuat produk dengan memasukan bahan-bahan yang dikumpulkan dalam modul pembelajaran tersebut. Setelah melalui proses desain dan produksi maka dihasilkan produk awal modul pembelajaran tersebut.

\section{Data Validasi Desain Modul}

Tujuan dari validasi desain adalah untuk mengumpulkan data sebagai dasar dalam penetapan media yang dikembangkan layak digunakan dalam proses belajar mengajar. Kegiatan uji coba dalam proses validasi dilakukan oleh ahli media. Peneliti memilih validator yang benarbenar memiliki kapasitas dalam bidang desain. Peneliti memilih Mahendra Puji Permana Aji, M.Pd. sebagai ahli media yang juga sebagai owner founder CV. Adjie Media Nusantara. Ahli materi yang dilibatkan adalah Moh. Nurkholis, M.Or. dan juga Dedy Yanis Setya Adi. S.Pd., mereka ahli praktisi Pencak Silat. Data diperoleh dengan cara memberikan produk awal berupa buku saku pembelajaran pencak silat beserta lembar evaluasi berupa kuisioner kepada ahli materi. Ahli materi menilai dan memberikan saran perbaikan baik secara tertulis maupun lisan. Ahli materi memberikan penilaian terhadap aspek kualitas materi pembelajaran dengan rerata skor keseluruhan sebesar 3,66 yang termasuk dalam kategori baik. Sementara hasil kuesioner dari Ahli media memberikan penilaian terhadap aspek kualitas materi pembelajaran dengan rerata skor keseluruhan sebesar 3,72 yang termasuk dalam kategori baik.

\section{Data Uji Coba Skala Kecil}

Setelah produk divalidasi oleh ahli materi dan ahli media serta telah mengalami perbaikan sesuai saran dan masukan para ahli, kemudian produk ini diujicobakan kepada guru dan siswa SMK Ngunut Kabupaten Tulungagung. Uji coba ini dilakukan dengan maksud untuk mengevaluasi produk yang dikembangkan. Dari uji coba yang dilakukan pengembang dapat mengetahui berbagai permasalahan, kelemahan, kekurangan ataupun kesalahan yang ada pada produk modul pembelajaran ini. Data yang diperoleh dapat digunakan sebagai dasar untuk melakukan revisi produk sebelum dilakukan uji coba produk.

Hasil uji coba skala kecil pada 3 guru SMK terhadap desain modul tutorial pencak silat memberikan nilai sebesar 3,50; 3,67; dan 3,54 yang mana termasuk kategori baik. Dari ketiga skor tersebut kemudian dirata-rata mendapatkan skor 3,57 sehingga dapat disimpulkan hasil penilaian guru SMK pada uji skala kecil terhadap pengembangan modul tutorial pencak silat dalam kategori baik.

Berdasarkan Tabel 3 hasil uji skala kecil pada guru terhadap modul yang dikembangkan menunjukkan bahwa modul berkategori baik. Sehingga, peneliti melanjutkan pada tahap uji skala besar. Hasil uji skala besar para guru yang ditunjukkan pada tabel 5 menunjukkan bahwa rerata skos sebesar 4,38 dengan kategori sangat baik. Sementara hasil penilaian setelah uji skala besar oleh para ahli mendapatkan rerata skor sebesar 4,38 dengan kategori sangat baik.

Tabel 2. Hasil Penilaian Validasi para Ahli terhadap Modul yang Dikembangkan

\begin{tabular}{ccccc}
\hline No. & \multicolumn{1}{c}{ Nama Ahli } & Nilai Total & Rata-rata Nilai Kuantitatif & Kategori \\
\hline 1. & Mahendra Puji Permana Aji, M.Pd. & 41 & 3,72 & Baik \\
2. & Moh. Nurkholis, M.Or. & 40 & 3,64 & Baik \\
3. & Dedy Yanis Setya Adi. S.Pd & 40 & 3,68 & Baik \\
& $\quad$ Rata-rata & 40,5 & 3,68 & Baik \\
\hline
\end{tabular}

Tabel 3. Hasil Penilaian Uji Skala Kecil para Guru terhadap Modul yang Dikembangkan

\begin{tabular}{clccc}
\hline No. & \multicolumn{1}{c}{ Nama Guru } & Nilai Total & Rata-rata Nilai Kuantitatif & Kategori \\
\hline 1. & Sugiyatno, S.Pd. & 38 & 3,50 & Baik \\
2. & Drs. Sudono & 40 & 3,67 & Baik \\
3. & Nanang Seminar, M.Pd. & 39 & 3,54 & Baik \\
& $\quad$ Rata-rata & 39 & 3,57 & Baik \\
\hline
\end{tabular}


Jurnal Keolahragaan 6 (2), 2018 - 136

Guntur Eko Saputro, Yulingga Nanda Hanief, Reo Prasetiyo Herpandika, Deny Pradana Saputro

Tabel 4. Hasil Penilaian setelah Uji Skala Kecil oleh para Ahli Materi dan Media terhadap Modul yang Dikembangkan

\begin{tabular}{ccccc}
\hline No. & Nama Ahli & Nilai Total & Rata-rata Nilai Kuantitatif & Kategori \\
\hline 1. & Mahendra Puji Permana Aji, M.Pd. & 45 & 4.42 & Sangat Baik \\
2. & Moh. Nurkholis, M.Or. & 48 & 4,36 & Sangat Baik \\
3. & Dedy Yanis Setya Adi. S.Pd & 44 & 4,00 & Baik \\
& Rata-rata & 45,67 & 4,26 & Sangat Baik \\
\hline
\end{tabular}

Tabel 5. Hasil Penilaian Uji Skala Besar para Guru terhadap Modul yang Dikembangkan

\begin{tabular}{clccc}
\hline No. & \multicolumn{1}{c}{ Nama Ahli } & Nilai Total & Rata-rata Nilai Kuantitatif & Kategori \\
\hline 1. & Sugiyatno, S.Pd. & 40 & 3,64 & Baik \\
2. & Drs. Sudono & 44 & 4,00 & Baik \\
3. & Nanang Seminar, M.Pd. & 44 & 4,00 & Baik \\
4. & Denie Rosmawati, M.Pd. & 41 & 3,73 & Baik \\
5. & Diyah Ismayawati, M.Pd. & 54 & 4,91 & Sangat Baik \\
6. & Wiji Astuti, M.Pd. & 53 & 4,82 & Sangat Baik \\
7. & Andre Reansyah, M.Pd. & 47 & 4,27 & Sangat Baik \\
8. & Sykles Wantina Haqiqi, M.Pd. & 51 & 4,64 & Sangat Baik \\
9. & Nanik Sri Astutik, M.Pd. & 53 & 4,82 & Sangat Baik \\
10. & Miming Yulianto, M.Pd. & 55 & 5,00 & Sangat Baik \\
& $\quad$ Rata-rata & 48,2 & 4,38 & Sangat Baik \\
\hline
\end{tabular}

Tabel 6. Hasil Penilaian setelah Uji Skala Besar oleh para Ahli Materi dan Media terhadap Modul yang Dikembangkan

\begin{tabular}{ccccc}
\hline No. & \multicolumn{1}{c}{ Nama Ahli } & Nilai Total & Rata-rata Nilai Kuantitatif & Kategori \\
\hline 1. & Mahendra Puji Permana Aji, M.Pd. & 47 & 4,27 & Sangat Baik \\
2. & Moh. Nurkholis, M.Or. & 53 & 4,82 & Sangat Baik \\
3. & Dedy Yanis Setya Adi. S.Pd & 48 & 4,36 & Sangat Baik \\
& Rata-rata & 49,33 & 4,48 & Sangat Baik \\
\hline
\end{tabular}

Kualitas komponen modul harus sesuai dengan apa yang telah ditetapkan oleh Badan Standar Nasional Pendidikan (BSNP) diantaranya adalah aspek kelayakan isi, bahasa dan gambar, penyajian dan grafis. Hasil pengembangan yang dihasilkan menunjukkan bahwa semua komponen yang meliputi kelayakan isi, bahasa dan gambar, penyajian dan grafis diperoleh kategori sangat baik.

Modul sebagai pegangan bahan belajar dalam proses pembelajaran harus disusun secara efektif dan terperinci. Penulisan modul yang ideal adalah modul yang dapat membawa siswa untuk bergairah dalam belajar dengan menyajikan materi sesuai dengan minat dan kemampuannya. Inti dari dibuatnya modul agar siswa lebih leluasa dalam belajar walaupun tidak di lingkungan sekolah dan dengan atau tanpa didampingi oleh guru (Syaugi, 2012).

Pengembangan bahan ajar modul penting dilakukan guru untuk meningkatkan kualitas dan efisiensi pembelajaran. Pengembangan modul memiliki komponen-komponen tertentu yang harus diperhatikan oleh guru agar dapat dihasilkan modul yang memiliki peran penting baik bagi guru maupun siswa (Syaugi, 2012).
Menurut Lasmiyati \& Harta (2014) kelebihan pembelajaran dengan modul yaitu (a) modul dapat memberikan umpan balik sehingga pebelajar mengetahui kekurangan mereka dan segera melakukan perbaikan, (b) dalam Modul ditetapkan tujuan pembelajaran yang jelas sehingga kinerja siswa belajar terarah dalam Mencapai tujuan pembelajaran, (c) modul yang didesain menarik, mudah untuk dipelajari, dan dapat menjawab kebutuhan tentu akan menimbulkan motivasi siswa untuk belajar, (d) modul bersifat fleksibel karena materi modul dapat dipelajari oleh siswa dengan cara dan kecepatan yang berbeda, (e) kerja sama dapat terjalin karena dengan modul persaingan dapat diminimalisir dan antara pebelajar dan pembelajar, dan (f) remidi dapat dilakukan karena modul memberikan kesempatan yang cukup bagi siswa untuk dapat menemukan sendiri kelemahannya berdasarkan evaluasi yang diberikan.

Dengan adanya pengembangan modul, banyak manfaat yang diperoleh siswa, diantaranya siswa dapat belajar dengan mudah. Selain dapat dipelajari diluar sekolah, modul juga dapat meningkatkan semangat siswa dalam menguasai materi pelajaran. Hal ini sejalan dengan pendapat 
Suryaningsih (2010) yang mengungkapkan bahwa manfaat modul yaitu: (a) meningkatkan motivasi siswa, karena setiap kali mengerjakan tugas pelajaran yang dibatasi dengan jelas dan sesuai dengan kemampuan, (b) setelah dilakukan evaluasi, guru dan siswa mengetahui benar, pada modul yang mana siswa telah berhasil dan pada bagian modul yang mana mereka belum berhasil, (c) bahan pelajaran terbagi lebih merata dalam satu semester, (d) pendidikan lebih berdaya guna, karena bahan pelajaran disusun menurut jenjang akademik. Teori yang menunjukkan manfaat modul pembelajaran juga diperkuat oleh hasil riset yang dilakukan Lasmiyati \& Harta (2014) yang mana pemahaman konsep siswa dapat meningkat dengan menerapkan modul pembelajaran. Peningkatan tersebut tidak hanya berdampak pada aspek pengetahuan saja, melainkan pada minat belajar siswa.

Namun pada pengembangan produk in terdapat beberapa kelebihan dan kelemahan. Kelebihan pengembangan produk ini ialah (a) siswa dapat mempelajari modul dengan mudah, karena penyampaian materi dalam modul disusun dengan adanaya langkah-langkah menguasai teknik dasar pencak silat, (b) modul yang disusun memiliki banyak representasi (multiple representations) sehingga mudah dipahami oleh siswa. Sedangkan kelamahan dari produk pengembangan modul tutorial ini ialah modul tutorial sebagai produk hasil pengembangan belum di ujikan efektifitasnya, sehingga perlu penelitian lebih lanjut untuk menguji kefektifan penggunaan modul tutorial pencak silat.

\section{SIMPULAN}

Pengembangan modul tutorial sebagai media pembelajaran pencak silat pada siswa SMK layak digunakan oleh para guru siswa SMK dalam menyampaikan materi pencak silat. Produk modul tutorial sebagai media pembelajaran pencak silat sebaiknya dapat disosialisasikan dikalangan Sekolah Menengah Kejuruan (SMK) agar para siswa dapat dengan mudah memahami materi pencak silat. Selain itu, perlu dikembangkan lebih dalam lagi materi pencak silat yang belum dipaparkan dalam modul tutorial tersebut.

\section{DAFTAR PUSTAKA}

Amrullah, R. (2015). Pengaruh latihan training resistense xander terhadap kemampuan tendangan sabit pencak silat Ramdani Amrullah. Jurnal Pendidikan Olahraga, 4(1), 88-100.

Arda, A., Saehana, S., \& Darsikin, D. (2015).
Pengembangan media pembelajaran interaktif berbasis komputer untuk siswa SMP Kelas VIII. E-Jurnal Mitra Sains, 3(1), 69-77.

Artyhadewa, M. S. (2017). Pengembangan model permainan sepak takraw sebagai pembelajaran pendidikan jasmani bagi anak SD kelas atas. Jurnal Keolahragaan, $5(1)$, 50. https://doi.org/10.21831/jk.v5i1.12804

Gristyutawati, A. D., Purwono, E. P., \& Widodo, A. (2012). Persepsi belajar terhadap pencak silat sebagai warisan budaya bangsa sekota Semarang Tahun 2012. Journal of Physical Education, Sport, Health and Recreations, 1(3), 129-135.

Hanief, Y. N., \& Sugito, S. (2015). Membentuk gerak dasar pada siswa sekolah dasar melalui permainan tradisional. Jurnal SPORTIF: Jurnal Penelitian Pembelajaran, 1(1), 100-113. https://doi.org/https://doi.org/10.29407/js _unpgri.v1i1.575

Kriswanto, E. S. (2011). The levels of understanding of physical education teachers of state junior high schools in sleman regency towards pencak silat instructions. In The Third International Seminar on Sport and Physical Education. Yogyakarta.

Lasmiyati, L., \& Harta, I. (2014). Pengembangan modul pembelajaran untuk meningkatkan pemahaman konsep dan minat SMP developing a module to improve concept understanding and interest of students of SMP. Pythagoras: Pendidikan Matematika, 9(2), 161-174.

Lestari, A. S. (2014). Pembuatan bahan ajar berbasis modul pada matakuliah media pembelajaran di jurusan tarbiyah STAIN Sultan Qaimuddin Kendari. Jurnal AlTa'dib, 7(2), 154-176.

Musfiqon, M. (2012). Pengembangan media dan sumber pembelajaran. Jakarta: PT. Prestasi Pustakaraya.

Nugrahani, R. (2007). Media pembelajaran berbasis visual berbentuk permainan ular tangga untuk meningkatkan kualitas belajar mengajar di sekolah dasar. Lembaran Ilmu Kependidikan, 36(1), 35144.

Nurkholis, M., \& Weda, W. (2015). Implementasi nilai-nilai pembentukan 
Guntur Eko Saputro, Yulingga Nanda Hanief, Reo Prasetiyo Herpandika, Deny Pradana Saputro

sikap dalam pencak silat terhadap perilaku mahasiswa Prodi Penjaskesrek UNP Kediri. Jurnal SPORTIF: Jurnal Penelitian Pembelajaran, 1(1), 100-113. https://doi.org/https://doi.org/10.29407/js _unpgri.v1i1.650

Prastowo, A. (2012). Panduan kreatif membuat bahan ajar inovatif. Yogyakarta: Diva Press.

Primasari, R., Zulfiani, Z., \& Herlanti, Y. (2014). Penggunaan media pembelajaran di madrasah aliah negeri se-Jakarta Selatan. EDUSAINS, 6(1), 67-72.

Sugiyono. (2011). Metode Penelitian kuantitatif dan kualitatif dan $R \& D$. Bandung: Alfabeta.

Suryaningsih, S. (2010). Pengembangan media cetak modul sebagai media pembelajaran mandiri. Jakarta: Salemba Empat.

Suryosubroto, B. (2009). Proses belajar mengajar di sekolah. Jakarta: Rineka Cipta.

Susilo, A., Siswandari, \& Bandi. (2016). Pengembangan modul berbasis pembelajaran saintifik untuk peningkatan kemampuan mencipta siswa dalam proses pembelajaran akuntansi siswa kelas XII SMA N I Slogohimo 2014. Jurnal Pendidikan Ilmu Sosial, 26(1), 50-56.

Suyatmin, S., \& Widiyanto, W. (2017). Pengembangan Modul pembelajaran perilaku hidup bersih dan sehat pada taman kanak-kanak 1 2. Jurnal Keolahragaan, 5(1), 90-99. https://doi.org/http://dx.doi.org/10.21831/j k.v5i1.12807

Syaugi, K. (2012). Pengembangan media pembelajaran modul interaktif las busur manual di SMK Negeri 1 Sedayu. Universitas Negeri Yogyakarta. 